\title{
Shakespeare's Richard III and Macbeth: A Foucauldian Reading
}

\author{
Zohreh Ramin \\ Faculty of Foreign Languages and Literatures, University of Tehran, Tehran, IRAN \\ e-mail: zramin@ut.ac.ir
}

\begin{abstract}
Reading for signs of power and its function in the world of Shakespeare's plays under the light of Michel Foucault reveals to be in stark contrast from traditional notions of the operation of power. An important Renaissance critic, E. M. Tillyard, has declared that Shakespeare's plays reflect faithfully the Elizabethan world order, remaining loyal to the hierarchical concept of power and its function in Elizabethan England. Such readings engage mainly with the protagonist of the plays, revealing the various aspects in which the world of the play moves toward order and harmony. A Foucauldian reading of the plays however is able to unveil more than merely a one-dimensional reflection of power structures of the society of the time. By focusing on Foucault's notion of power relations at work in the society and also his emphasis on the marginalized aspects, this study aims to reveal how power relations in the two plays under consideration, Richard III and Macbeth, can reveal versatile experiences.
\end{abstract}

Keywords: Power, world order, marginalized, Richard III, Macbeth

\section{INTRODUCTION}

According to Michel Foucault, the operation of power can be found most clearly by observing the relationship between the individual and social structures and institutions (Mills, 2005, p.33). Foucault views this relationship as reciprocal. It is not only the effect of power, exercised in the hands of institutions and authorities that concern him. He is also interested in the way power operates in the everyday relations between the individual and the social structures or institutions. What strikes as interesting in Foucault's theory is his positive view on power; unlike earlier Marxist notions which conceived of power as a negative force, with negative oppressive and confining effects. Foucault wishes to look at the productive side of power, how and in what sense power can be productive and positive. For Foucault, it is not merely the reflection of power as oppressive that is significant. He wishes to uncover those aspects of power which are resisted by individuals, rather than being taken for granted. Foucault is interested in a bottom-upwards, rather than a top-downward view of the function of power. His view can be summarized, according to Sara Mills as "his focus on the way power relations permeate all relations within a society, enables an account of the mundane and daily ways in which power is enacted and contested, and allows an analysis which focuses on individuals as active subjects, as agents rather than passive dupes" (Mills, 2005, p. 34).

Another factor which distinguishes Foucault's view on power from earlier theoreticians is that contrary to earlier beliefs Foucault declares that power is not something that can be possessed. Power is something which is exercised, and as he mentions in The History of Sexuality (1978), power should be seen as something which does something, functioning in a network of associations, rather than an isolated effect, employing individuals as its vehicle, rather than final destination. Therefore, power is a function, rather than a possession, and the requirement of a function is to be performed. Power relations are multiple, having different forms in different contexts. He is thus focusing on power as "Ideological State Apparatus," rather than "Repressive State Apparatuses" (Mills, 2005, pp. 35-36) and is thus following his teacher, Louis Althusser. Our job then, he declares, is to reveal the concealed things in the relations of power. Rather than centralizing power, Foucault disparages it to various aspects of individuals; the family, church, and institutions. Power thus becomes a material practice.

Foucault declares that power, seen from its productive aspect, is capable of creating forms of behavior and 
events, opposing earlier Marxist and feminist notions of power as oppressive. The state, according to Foucault, only constructs relations which locate individuals as means to account for the function of the political system. In other words, no matter what kind of state rules, power will function in much the same way as before. There is only shift in kind.

Shakespeare's plays have been studied from different perspectives but perhaps the reason why a Foucauldian reading is relevant is Foucault's specific view of resistance, rather than oppression. Foucault's theory gave rise to New Historicism and Cultural Materialist on the basis of uncovering the struggles and resistances prevalent wherever power is at work. It is at this point in which Foucault diverges from conventional notions of power, believing resistance to be "written in" to the exercise of power. Unlike earlier notions, Foucault declares individuals as active participants, rather than passive recipients, in resisting and struggling against power. Thus we need to describe the ways in which resistance operates as part of power.

Foucault is interested in the techniques and strategies employed by institutions and authority. One such technique is self-regulation. Individuals internalize the behavioral codes of the institution or authority. The term "Panopticon" is drawn from Foucault's work regarding such structures of discipline. Foucault's idea of panopticon uncovers those aspects of Shakespeare's plays which traditional critics including Tilliyard have left intact. As we shall see, in Macbeth, it is the function of this "internalized disciplinary practice" (Mills, 2005, p. 45) which torments the mind of both Macbeth and Lady Macbeth, resulting in their regretful behavior.

However, Foucault believes that power relations are in the end unsuccessful and are incapable of achieving a total domination. Due to the persistent resistance and struggles, power is never able to achieve absolute unity. Not even is the state unitary, for conflicts and struggles exist even at the highest levels. It is not always the state that dictates limitations for the individuals. With their demands and resistances, individuals are also capable of pressing confinements upon the state. It is our job to find these marginalized, neglected aspects of power relations at work in literature, rather than observing power as merely oppressive. The purpose of the present paper is to account for the differences of the function and operation of power and to employ Foucault's bottomup model for signs of resistance and struggle within the world of Shakespeare's Richard III and Macbeth.

\section{RICHARD III}

Tillyard observes Richard III as a play which displays God's plan as restoring England to prosperity, order and harmony (in Taylor \& Loughrey, 1990). He believes Shakespeare delineates God's mercy and justice to England and this is the main business of the play despite its centrality on the villainous figure of Richard. He seeks for Elizabethan world order and unity and detects it in the final outcome of the play, justifying his view through Richmond's first words after the victory "God and your arms be prais'd, victorious friends/ The day is ours, the bloody dog is dead." (Act V, Scene v, 1-2). Thus the theme of the play is justified as power shifts form the hands of the villain to the hands of the redeemer. To support this ideology, Tillyard evokes religion as backing up this transmission of power from Richard to Richmond as just and fair to country, state and the public. In other words, his focus is on the representation of final unity and harmony while Richard and Richmond are merely instruments of vice and virtue. The main objective of the play, as with four other plays according to Tillyard is "the steady political theme: the theme of order and chaos, of proper political degree and civil war, of crime and punishment, of God's mercy finally tempering his justice, of the belief that such had been God's way with England." (in Taylor \& Loughrey, 1990, p. 42).

However, even in this play we are able to uncover signs of contingencies not only in the character of Richard himself, but also in the characters of the female figures and even more interestingly, in the common public of the society. The play starts out with a significant soliloquy by Richard to the audience. At the very beginning, we learn that Richard is obsessed with his deformity and attempts to establish intimate relations with the audience, foreshadowing the reasons for his later action:

Why, I in this weak piping time of peace

Have no delight to pass away the time,

Unless to spy my shadow in the sun

And descant on mine own deformity.

And therefore since I cannot prove a lover

To entertain these fair well-spoken days,

I am determined to prove a villain

And hate the idle pleasure of these days.

(Act I, Scene i, 33-40)

Merely to perceive Richard as the true villain, overthrowing his own brothers and family to gain power over others would leave intact many significant facts about Richard and the apparently minor individuals in the play. Richard is successful at improvising others in the play, for his own advantage 
but this improvisation is not always unproblematic, for he must continuously destroy those who threaten his position even after he is crowned king.

According to Foucault, power is not something one can gain absolutely. We only have power shifting from one form of relation into another. In this play we observe how power shifts from the very beginning of the play. Apparently, everything is calm and peaceful, the battle has been won and King Edward IV sits on the thrown, in what seems to be an ordered and wellstructured community where everyone is exactly where they should be; "Now is the winter of our discontent/ Made glorious summer by this son of York." (Act I, Scene i, 1-2). However, this is merely the lull before the storm. Where there is power at work, resistance is an indispensable aspect of power and consequently it comes as no surprise that already, resisting voices against the King are beginning to take shape in the form of Richard.

Therefore we find in the opening scenes Richard as an individual who is largely abhorred by many of those surrounding him. Yet the fascinating aspect of his character lies in his masterful power in playing with words and language. He manages to manipulate not just those who are not aware of his intentions, but those who have already had a chance to glimpse his evil nature. One such scene is when Richard woos Queen Ann, whose father-in-law, father and husband have been murdered by Richard directly or under his orders. Even more intriguing is the fact that he manages to derive Anne's acceptance in the scene of the funeral she is attending for the dead King Henry VI. Richard enters the scene, ordering the group of men carrying the coffin to halt the procession and although strongly rejected and detested by Ann, and despite his physical deformity, manages to win her hand in marriage in the very same scene. The relevance of this scene in the play expresses the productiveness of the operation of power, which in this specific scene, is verbal expression. Richard is powerful with words and is masterful in exercising this ability to transform entirely the opinion of others, depicted in its extreme form in this scene.

To exercise power over others, one need not necessarily be the head of a state or an absolute monarch. This is proven by Richard in the course of the events of the play. Under the seemingly peaceful power-structure of King Edward's monarchy, Richard is already portraying signs of resistance. Yet, in Foucauldian notions of power, it is not King Edward, as the absolute figure of monarchy that Richard is resisting against. $\mathrm{He}$ is in fact opposing power as a complex, external force. He fails to realize that even if he manages to finally take over and usurp the thrown, he will never conquer its powerful force. It is due to this factor that even after he is crowned King, he continuously needs to murder, destroy and imprison signs of resistance. He does not achieve absolute monarchy, even in the position of the King of the state. Richard only becomes a vehicle for the exercising of power relations. He fails to apprehend that he can never obtain it under his complete control. It is power that controls him and his world.

The resistant nature of the female figures of the play is also worth mentioning at this point. One such instance is Queen Elizabeth, wife to the sickly King Edward. Elizabeth senses the hostility of Richard at the early stages of the play, and Queen Maragaret, in her famous words, curses Richard, remarking the transience of power. Richard may apparently appear to cover up his villainy from others, but with Queen Elizabeth and Queen Margaret, he does not succeed. They are sites of struggle and resistance against Richard's manipulative and improvisational nature. Queen Margaret has already experienced the transience of power for she has at moments reached the zenith of power and her experience has taught her nor to trust it. Irene Dash (in Taylor \& Loughrey, 1990) has believed that this rise and fall in power of the female figures in the play is due to the nature of their being caught in patriarchal worlds of power structure.

"Shakespeare presents a range of women in this tetralogy, one of whom, Margaret, provides the overall arch, giving this boldly spreading group of dramas a unity. Although she does not dominate any single play, she links the works from the end of 1 Henry VI through Richard III, provides continuity, and allows one to observe how women must contend with the power structure in a patriarchy." (p. 76)

However, according to Foucault, this "paradox of power" is not exclusively allocated to the female widows, having its roots in a necessarily patriarchal structured society, but is in fact the prevailing nature of power in general. If there is a paradox, it is applicable to all members of the society, and its cause lies in the very nature of power itself.

Even if the female stand powerless, occupying no specifically significant position in the court, they are not totally disarmed and inactive. The most important reflection of this embodies in the figure of Queen Margaret, the weakest and most powerless women of the play. A woman who once enjoyed being the Queen of her country, she now roams about the palace, relying on what charity those who have now 
taken her place offer her. However this does not denote that she is entirely helpless. She manages to exercise power and resistance in opposition to Richard through the powerful curse she directs at Richard and others, which does in fact take effect and control the movement of the play towards not only the mental and physical destruction of Richard but even Queen Elizabeth, whom she cursed "die, neither mother, wife, nor England's queen." (Act I, Scene iii, 196-206).

Richard is the total embodiment of absolute power neither before nor after his usurpation of the throne. He must remove many obstacles to arrive at the position of monarchy and when he does finally reach it, he must continue his effort to maintain it. That he manages to distort the traditional shift of power from father to sun, after King Edward, reveals that power is not something one can obtain or let slip away. Richard's own downfall is yet another justification for this notion.

Power struggle is at work in the nation between not merely the monarch and those under his power but on a larger scale in the lives of ordinary people. Shakespeare provides a scene in which the audience is presented with common public and their concern for the power struggles in the court. They are aware of the conflict among the members of the royal family and see it as a threat to the state. It is not only the threat of the legal heirs to the throne which Richard must avoid but also the threat of the common public. This becomes even more significant when justification is required by Buckingham to the common people of why Hastings needed to be trialed, to which the scrivener reacts critically:

Here is the indictment of the good Lord Hastings;

Which in a set hand fairly is engrosse'd,

And mark how well the sequel hangs together:

Eleven hours I have spent to write it over,

For yesternight by Catsbey was it sent me;

The precedent was full as long a-doing;

And yet within these five hours Hastings liv'd,

Untainted, unexamin'd, free, at liberty.

Here's a good world the while! Why who is so gross

That cannot see this palpable device?

Yet who so bold but says he sees it not?

Bad is the world; and all will come to naught,

When such ill dealing must be seen in thought. (Act III, Scene vi, 1-14)

These are all deeds that must be carried out since the threat of disobedience always exists among the common public. Holderness sees this as a mani- pulation of history that "[t]he manipulation and fixing of legal documentation is manifestly an attempt to rig the verdict of history, to put in place a phoney record from which a particular interpretation of the past can then be drawn." (Holderness, 2000, p. 96). However, the critical reaction of the scrivener, recognizing the trick as a "palpable device" which any simpleton can conceive reveals that it is not just the monarch who confines and represses the individuals. The common public also enforces limitations on the king since they are constant sites of resistance and contradiction to the monarch's supremacy and the manipulation of truth does not go unnoticed to the public as reflected clearly in this scene. The monarch is no longer the ultimate site of power, but himself a subject to its operation.

The young prince, King Edwards's oldest son, is well aware of his uncle's deceit and is a rival to his uncle. His witty remark reveals him to be a clever opponent not only as a potential heir to the throne, but also as a skillful employer of words. When Richard speaks with the intelligent young prince, he is certainly not fooled by him. When Prince Edward declares, "I want more uncles to welcome me," (Act III.i.6), he implicitly remarks that he suspects Richard responsible for conspiring against Clarence, Richard's older brother. He may also be referring to Rivers, Gray and Dorset, his relatives from his mother's side. Rivers, Grey and Dorset are yet other threats which must be removed to decrease any voice of resistance to Richard's authority.

Buckingham, Richard's ally in his conspiracy, is also required to manipulate the cardinal to "pluck" the younger prince out of the sanctuary where his mother, the Queen, has taken him and where they are supposed to be safe from harm. The cardinal's resistance does not last long as he is persuaded by Buckingham's deceitful reasoning.

By fabricating his own narrative, Richard manages to manipulate others and inscribing them inside his narrative. This recalls a similar method employed by Iago in Othello. The difference between the two characters, however, is that while Iago manages to conceal his improvisation until the end of the play, Richard is not successful in concealing his intentions from everyone in the play. Queen Margaret, Elizabeth, Prince Edward, Buckingham and even the common public are able to conceive of his evil intentions and carry out their utmost abilities to resist him.

In this play, it is not only Richard that is the center of attention. Power relation is strongly at work in the individual's employment of words, and their skill at 
manipulating others through this powerful weapon. Queen Margaret's poignant curse, Richard's wooing Ann, Buckingham's enforcing of the Cardinal, Prince Edward's replies to his uncle, Clarence's entreating to his executers are only some of such instances of power at work.

Foucault's bottom-up model of power is discernible also in another scene involving the common public. The commoners do not merely remain passive recipients of the oppressive ruler. The very fact that Richard needs to give a report of the reason for Lord Hastings's trial reveals yet another aspect of the constraint placed by the public to the King. The reaction to the reception of the news, which clearly reflects their disbelief of the false report, expresses their alertness and their reaction to the King's power. In fact, it is ironical that by murdering those whose right is to the throne, Richard manages to silence them, but in silencing the common people he remains helpless. They reject and refuse to accept him as their King. It is again ironical that his own brothers never realized his deceptive character, while the commoners whose lives are outside the court seem to have a better and closer understanding of Richard and his foul intentions. The two scenes involving the commoners reveal them not only as instances of resistance but their active participation in the structure of power relations.

It is not only the external forces in the figure of the commoners which confine Richard's authority. Richard succeeds in becoming the King of the state, which ought to denote absolute authority, but a close scrutiny reveals otherwise. He never experiences a serene state once he is crowned and dreams continue to haunt him, reminding him of Queen Margaret's curse.

Even Buckingham, who has been his ally all along, resists Richard at a point which apparently seems to be Richard's peak of power. His refusal to execute the young princes inaugurates his opposition and final downfall of the King. Richard is thus threatened from all sides. No one is to be trusted since power is exercised by all individuals in all circumstances. Merely occupying a high social position cannot secure and guarantee authority. Although Richard's exercise of power at the beginning of the play may have led us to praise him for his self-assured confidence, yet this fades by the end of the play as Buckingham's open declaration of resistance marks the beginning of Richard's disintegration.

When tables have turned around by Act four, Scene four, Richard no longer manages to exercise power.
He panics when he hears of Richmond's preparation for attack and reveals his helplessness. Richard's loss of power is also clearly discernible in his inability to employ powerful, forceful and appealing verbal expressions he used as a powerful weapon against his opponents. There is a stark contrast between his early employment of fanciful words to persuade Ann, an apparently impossible task, versus his inability to respond to the violent language of his mother, the duchess, "Thou toad, thou toad, where is thy brother Clarence?" (Act IV, Scene iv, 7). At this point, Richard becomes so desperate and helpless that he can only ask the musicians to sound the noise of drums and trumpets louder to drown his mother's words.

Yet, still he is conspiring and planning to secure his grasp of the throne by asking to marry Elizabeth, the daughter of Queen Elizabeth. This time, unlike the scene of wooing Ann, it is he who is deceived by Queen Elizabeth, who has already promised her daughter's hand to Richmond, which she reveals only after having seemingly agreed with Richard's proposal.

It is in these scenes which we can observe the shifting of power gradually from Richard. No matter how hard he tries to hold on to it, power lets go off Richard, seeking to exercise in another individual. Power is not, according to Foucault, something you decide to achieve or let slip away by your own accord. Neither is it exercised solely by one absolute individual even if that individual occupies the head of the state.

That Richmond finally manages to overthrow Richard is justified in the play and as being the requirement of God's justice: those evil men will be overthrown through their own wickedness. Yet there is more to it than a mere triumph of good over evil. This is merely another instance of the operation of power which justifies Richmond's right to the throne after a villainous ruler. Just as Richard never managed to stand for the unified, absolute figure of monarchy, we can predict the same continuing during the reign of Richmond.

It is power that finally leaves Richard, but this power needs a new locus to perform and exercise its force. This locus is now Richmond. Just like Richard, Richmond also attempts to become the absolute monarch, yet we know that this unification and that gathering of all power relations and structures in one focused center is a futile attempt. 


\section{MACBETH}

In the second play under consideration in this study, more or less the same views toward power-relations based on Foucault's theory can be observed. The two most significant notions: that power can never be observed in its absolute form, and that resistance is a requirement to the existence of power, have been portrayed, although variations to the operation of power relations and the nature of resistance take on a new form in this play.

This plays portrays Macbeth as a brave and powerful soldier whose lack of virtuosity prepares the ground for his downfall. To see the play merely in this sense would again be missing some significant factors about the operation of power. This would mean expecting unification and ultimacy through the operation of power structure. However, as we have already observed in the previous play, such views are excessively exclusive. To account for other important factors regarding not only the most outstanding figure of the state, but even the seemingly lesser important characters in the world of the play, our evaluation of the operation of power relations can be a more inclusive one.

Like Richard, Macbeth manages to overthrow the King yet to secure obedience; he must continue committing more murders. It is as if resistance runs in a parallel line with power; there is no point at which these two will ever meet. In other words, neither is able to overcome the other. Any form of conquest by one side is transient and will soon be required to take up the less privilege position.

One significant point of difference between Macbeth and Richard lies in the form of power relations in the play. The operation of power structures in this play takes on a more abstract form as it dominates the play through various aspects. One such aspect is in the union and later disintegration of Macbeth and Lady Macbeth. Lady Macbeth is Macbeth's complement, encouraging him whenever he becomes hesitant. This is one way in which power exercises itself on the individual. Sigmund Freud, basing his ideas on the studies of Ludwig Jekels, has observed Macbeth and Lady Macbeth as one character split in two personages, understandable only once they are taken in unity, "together they exhaust the possibilities of reaction to the crime, like two disunited parts of a single psychical individuality, and it may be that they are both copied from a single prototype." (in Sinfield, 1992, p. 44). However, she does not occupy this powerful position for long. With her breakdown after the death of the king, she no longer becomes the suitable vehicle for the operation of power and consequently looses any control over herself and Macbeth.

Another important operation of power in the play is that imposed by the witches. The witches have an extremely enigmatic nature and the reality of their existence has been long under dispute. However, if looking at the play in the light of Foucault's view of power, they represent the force of power and its operation upon the lives of individuals. The force they employ however is received differently by different individuals. Macbeth and Banquo are both present when the witches articulate their prophecy. While in Macbeth, this becomes an evil derive, in Banquo it only stirs him into thought, never translated to action. The later appearance of Banquo's ghost at the banquet is a very appropriate method to reflect the distinction between the paths each has taken.

As with Richard III, Macbeth also opens with the time of rule of a virtuous king. The series of events which the play undergoes has a more or less similar structure to the earlier play. The villain usurps the throne through violent deeds to secure his position. He continues the violence, yet he is soon over throne by another apparently virtuous King who is to restore order and harmony to the state.

Although the structures of the two plays reflect a similar attitude, the operation of power structures and the nature of resistances in this play differ markedly from the former. Macbeth becomes the locus for the struggle between power and resistance, between bravery, ambition and self-doubt. This is in stark contrast with Richard, who not until the very end doubted his exercise of evil over others. So while the nature of resistance had an external source in the former play, here it takes on an internal shape within the very character of Macbeth. Richard engaged in more evil and villainous deeds than Macbeth, and while Richard had a more powerful character, he acted only according to his own reasoning. Macbeth acts according to the influence of others; first the witches and later Lady Macbeth and when there is no force to support him, he disintegrates.

If in Richard it is an external resistance, those of the common public as well as others belonging to the royal family and the nobles which finally lead to his downfall, in Macbeth it is an internal resistance, that is, the guilt and self-doubt which finally manage to conquer the protagonist.

Before murdering Duncan, Macbeth is plagued by worry to the point of aborting the crime. His final 
action is only due to the persistence of Lady Macbeth. However, as her powerful character begins to disintegrate due to the heavy burden of guilt, so does Macbeth. Macbeth oscillates between fits of passionate desire to secure the throne, terrible guilt, and absolute pessimism. Only when in the battle, internal turmoil does not affect him.

In the strong and powerful figure of Lady Macbeth, it becomes evident that power does not recognize gender. Shakespeare disrupts gender differences in this play. We can never determine exactly weather the witches were really women, or men because of their strange appearances. Lady Macbeth desires to lose her femininity, "you spirits/ That tend on mortal thoughts, unsex me here, / And fill me from the crown to the toe top-full/ Of direst cruelty" (Act I, Scene v, 38-41). According to Marilyn French, this violation of gender roles serve to reflect "moral ambiguity" and "confusion in the hierarchies of nature." (in Sinfield, 1992, p. 18).

Lady Macbeth manages to propel her husband into murdering Duncan by invoking his manhood, so that he feels that in order to prove his manhood, he must carry out the evil deed; and in that sense, she manages to manipulate him through providing him with false support: his manhood. This feeling of false security also surfaces in the speech by the witches who are aware of Macbeth's intention to ask them for the prediction of his future, whose reply is intended to merely "draw him to his confusion" (Act III, Scene $\mathrm{v}, 29)$.

Therefore, as we have observed, the witches are powerful manipulators who manage to influence the lives of many people, and yet their own nature remains enigmatic, which can be viewed in relation to the mysterious nature of power itself.

As in the previous play, how the individual's struggle to control power is ineffectual as it is power that controls him. Lady Macbeth manages to impel her husband to murder the King and fulfill the ambition of both of them, yet even she cannot become the locus for the operation of absolute power in its negative form as she fails to suppress her inner resistance: the feeling of guilt and retribution.

The important lengthy soliloquy spoken by Macbeth provides a glimpse into his inner resistance:

If it were done when't is done, then't were well

It were done quickly: it the assassination

Could trammel up the consequence, and catch

With his surcease success; that but this blow

Might be the be-all and the end-all here,
But here upon this bank and shoal of time,

We'd jump the life to come, - But, in these cases,

We still have judgment here, that we but teach

Bloody instructions, which, being taught, return

To plague th' inventor ... (Act I, Scene vii, 1-10)

Here, Macbeth is obsessed with committing murder, which is not an easy task for him to conduct. Unlike Richard, who never for once doubted the rightness of his deed, Macbeth is haunted by the sense of guilt and self-doubt. In other words, Macbeth has internalized too strongly within him the panoptical condition Foucault refers to in his theories. He becomes his own judge. On the one hand are his drives towards ambition and power. On the other are the consequences of disloyalty to the King. The same applies also to Lady Macbeth. She starts out as an apparently powerful character who is well aware of the weak nature of her husband and manages to manipulate him to do what they both desire. In order to improvise her husband to carry out the murder of the King, she questions her masculinity, since it is supposed to be the source of evil and violence, but in fact, power knows no gender. It is the exercise of power, its enactment in different individuals that is of interest. To Macbeth, Lady Macbeth's boldness and masculinity is heroic and warrior-like to the extent that he wishes her to "bring forth men-children only," (Act I, Scene ii, 72).

As Foucault mentioned, power does not secure ultimacy. Macbeth is entirely based on the significance of resistance to power. Macbeth betrays his king, the supposedly ultimate monarch, therefore supporting Foucault's theory that power cannot successfully suppress. Yet, power needs to be constantly performed. To secure his position and to destroy the risk of revelation of his intentions, Macbeth must also destroy Banquo, whose knowledge of the witches' prophecy makes him a potential threat to Macbeth's conspiracy.

After his coronation, Macbeth springs into action, seizing control of the nobles and becoming King of Scotland. However, other characters cast subtle suspicion on him. One such resistance occurs right after Macduff's realization of Duncan's death. He is suspicious of Macbeth's hasty and violent killing of the chamberlains. Also, his decision to return to Fife rather than to attend Macbeth's coronation is open declaration of his opposition.

Foucault's bottom-up model is also applicable in this play as we are presented with a scene involving the dispute among minor characters in the play. Ross and an old man talk of the unnatural occurrences in the 
weather and the behavior of the animals, originating in the heavens outrage at man's conduct and reflected by the nature of darkness and night:

Ha, good father,

Thou seest, the heavens, as troubled with man's act,

Threatens his bloody stage: by the clock't is day, And yet dark night strangles the traveling lamp. Is't night's predominance, or the day's shame, That darkness does the face of earth entomb, When living light should kiss it? (Act II, Scene iv, 4-10)

Even those who were not directly related to the monarchy are aware of the evil nature of Macbeth, seeing his deeds as reflected in the darkness that envelopes the state both physically and metaphorically. They are not mere passive recipients but are watchful participants in the operation of power, themselves representing it in different ways.

Macbeth manages to manipulate others, the King and Banquo, by invoking in them the feeling of false security. It is ironical that he himself is destroyed also by the same false feeling the witches create in him. They are apparently lower than him in social standing but occupying a privileged position in relation to exercising power. They tell him the truth, "none of woman born/ shall harm Macbeth" (Act IV, Scene I, 96-97), that he will die only when Birnam wood moves to Dunsinsm Hill. However, they do not tell him that such seemingly impossibilities are in fact possible probabilities.

To destroy their opponents and to obtain power, Macbeth and Richard need to conceal their true nature. This is voiced clearly by Lady Macbeth's statement that Macbeth must "look like the innocent/ But be the serpent under't." (Act I, Scene v, 63-64). However, after the murder of the king, Macbeth and Lady Macbeth change roles and now it is Macbeth who reminds Lady Macbeth that they must disguise their unease to "make faces visors to hearts/ Disguising what they are." (Act III, Scene ii, 35-36). Although they thought that merely by killing Duncan, it would be "done", meaning that they would become the absolute, ultimate and all-empowered rulers of the state, it only appeared to be a starting point of a vicious circle, never reaching a point of final closure. While each murder Macbeth commits or commissions is intended to bring him security, the deeper his arms are entrenched in blood, the more violent and horrified he becomes. Rather than managing to become the absolute monarch, his many references to animal imagery reflect his disintegrated state of mind and inner turmoil: "full of scorpions is my mind, dear wife." (Act III. Scene ii, 37).
The play gradually manages to evoke the feeling in the audience that only through Macbeth's death can order be restored and the audience now awaits his demise, making it appear as a just act. Just as in Richard III, it is by now the time for the villain to be overthrown from power, to shift power to a position which will seem to ultimately bestow unity and moral order after chaos and anarchy. Yet, this is a merely superficial expectation since what is happening here is that power is shifting from one form to another.

What both Macbeth and Richard failed to recognize was the every fact that they could never ultimately hold control of power. It was the nature of power that held them captive. The false feeling of security experienced by both finally led to their collapse.

\section{CONCLUSION}

The two plays examined in the present study were selected due to the significant similarity between them. However, a closer scrutiny of the plays under the light of Foucauldian analysis revealed a number of salient differences.

Both had a structure more or less similar in nature as they focused on the central character whose name bore the title of the play. Both characters set out to capture the crown. The first half of each play concerned itself with the divergent stages in the hero's successful attempt to eradicate everything that stands between him and his ambition. The second half of each play looked at the step-by-step disintegration of that achievement and the stripping away of all that the hero worked so hard to achieve. Both concluded with the death of the central hero in battle by the hands of a military opponent associated with restoring virtue to the state.

This similarity, however, goes beyond mere structural closeness, to cover Foucault's notion of power. Both plays involve a hero in the quest for power to gratify his ambition to become the ultimate monarch and to silence any ominous voices which are potential threats to his reign and any signs of resistance. That they both finally fail is yet another point of comparison between the two plays but to stop there would mean missing some significant aspects of the play.

An expansion of thirteen years separated the creation of Richard III from Macbeth. The world of the former play is set in the medieval morality play and consequently divine support is invoked to justify power and order. In the latter, however, no such simple formulaic moral principles are discernible. The operation of power as a system of net-like 
organization is observable in both plays, taking on a different shape in each.

In Richard III, the chain of power is continued from King Edward, to Richard and later to Richmond. To maintain stability and unity, which is what power seems to be employed and desired for, is related very closely to God's grace. Richard, although a villain, becomes the agent of God since those he destroys at the early stages of the play have themselves been originators of evil deeds (Clarence and Lord Hastings are two significant instances). However, he exceeds his limit and is finally punished by another agent of God's grace, Richmond, who is also attempting to carry out God's justice and so the net-like organization of power relations continues, never achievable in its absolute form.

Another significant characteristic of this play is the power of the employment of words and language. Many of the characters of the play manage to manipulate others merely by words. Although this may be observable in many other works by Shakespeare, its significance here is the force of transforming apparently impossible situations (Queen Ann's detestation and acceptance of Richard's marriage proposal in one short scene, the cardinal's acceptance to remove forcefully the young prince from the supposed security of the sanctuary of the church, only after thirteen lines of dialogue with Buckingham) in what seems a fascinatingly short expanse of time.

The nature of resistance, an inevitable aspect of power, is another relatively divergent form in this play. Richard is never in conflict with himself. He is a resolute and self-confident individual who has a mind firmly set on his goal. However, the bottom-up model of Foucault is here portrayed through the external points of resistance in the play which include not only major characters of the court, but more importantly, the common public who represent a constant threat to Richard's power.

In Macbeth, the function of power takes on a quite different form and nature than that of the divine order of Richard III. The entire play is governed by a mysterious force, projected by the fascinating presence of the witches. They manage to conduct the story of the play as they forcefully manipulate Macbeth. They manage to misguide him by giving him a false feeling of security. Macbeth himself also employs this strategy when he destroys the King and Banquo. Lady Macbeth also manages to utilize this strong weapon, by invoking in Macbeth a false feeling of violent and strong masculinity, an originally cultural construct, to resolve his dilemma, and hence the chain-like operation of power is portrayed in the play.

The inevitable presence of resistance is also discernible but there is a difference in the nature and origin of resistance in this play. While Richard was a powerful, self-confident individual who never doubted his actions, Macbeth is the major locus for resistance within himself. His mental dilemma of bravery and courage versus ambition at times prevent him from moving on. He becomes an appealing paradigm of panopticism, by becoming his own punisher. The hallucinations are very strongly related to this concept. In the character of Lady Macbeth also appears this internal policing, as Foucault regards, when she finally is unable to live under the burden of guilt. Resistance in this play takes on a significantly internal shape as it functions to disintegrate those who had come to believe it possible to become the ultimate signs of power.

That power functions in a net-like pattern and that it is constantly accompanied by resistance is an indispensable aspect of both plays. Yet it is the form and shape it takes to exercise and to constantly perform itself and the nature of resistance is what distinguishes the two plays.

\section{REFERENCES}

Holderness, G. (2000). Shakespeare: The histories. London: Macmillan Press.

Mills, S. (2005). Michel Foucault. London: Routledge.

Sinfield, A. (1992). New Casebooks. Macbeth. London: Macmillan.

Taylor, N. \& Loughrey, B. (1990). Shakespeare's early tragedies: Richard III, Titus Andronicus and Romeo and Juliet: A casebook. London: Palgrave Macmillan. 